\title{
PERLINDUNGAN HAK KONSTITUSIONAL BURUH
}

\author{
Wilma Silalahi \\ (Panitera Pengganti di Mahkamah Konstitusi) \\ Email : silalahiwilma@gmail.com
}

\begin{abstract}
Indonesia as a democratic rule of law places the rights of citizens as part of the basic rights guaranteed and protected by the state. The rights of citizens are further regulated in the 1945 Constitution as the highest basic law, hereinafter referred to as constitutional rights. However, in its implementation there are still often violations of labor rights. Over time workers who feel their constitutional rights are impaired by the enactment of norms in the Manpower Act submit a judicial review to the Constitutional Court related to the conception of protecting labor rights. The writing of this article uses the normative legal research method. The conclusion of this article is that the concept of protection of labor rights in legislation that guarantees the constitutional rights of workers or workers' normative rights that can be broadly grouped into four, namely economic rights, political rights, rights that are medical nature, and social rights. Conception of Labor Rights Protection According to the Constitutional Court as reflected in Decision on Case Number 012 / PUU-I / 2003, is an interpretation of the Constitutional Court's law on the 1945 Constitution related to the examination of the Labor Law.
\end{abstract}

\section{Keywords : Labor Rights, Constitutional Court}

\begin{abstract}
Abstrak: Indonesia sebagai negara hukum yang demokratis menempatkan hakhak warga negara sebagai bagian dari hak-hak asasi yang dijamin dan dilindungi oleh negara. Hak-hak warga negara tersebut selanjutnya diatur dalam UUDNRI 1945 sebagai hukum dasar tertinggi yang selanjutnya disebut hak-hak konstitusional. Akan tetapi dalam implementasinya masih sering terjadi pelanggaran hak-hak buruh. Seiring waktu buruh yang merasa hak konstitusionalnya dirugikan oleh berlakunya norma dalam UU Ketenagakerjaan mengajukan pengujian undang-undang ke Mahkamah Konstitusi terkait dengan konsepsi perlindungan hak-hak buruh. Penulisan artikel ini menggunakan metode penelitian hukum normatif. Kesimpulan dari artikel ini adalah bahwa konsep perlindungan hak buruh dalam peraturan perundang-undangan yang menjamin hak-hak konstitusional buruh atau hak-hak normatif buruh yang secara garis besar dapat dikelompokkan menjadi empat, yakni hak yang bersifat ekonomis, hak yang bersifat politis, hak yang bersifat medis, dan hak yang bersifat sosial. Konsepsi Perlindungan Hak Buruh Menurut Mahkamah Konstitusi sebagaimana tercermin dalam Putusan Perkara Nomor 012/PUUI/2003, adalah merupakan penafsiran hukum Mahkamah Konstitusi terhadap UUDNRI 1945 terkait dengan pengujian Undang-Undang Ketenagakerjaan.

Kata kunci: Hak Buruh, Mahkamah Konstitusi
\end{abstract}




\section{A. Pendahuluan}

Perumus Undang-Undang Dasar Negara Republik Indonesia Tahun 1945 (selanjutnya disebut UUDNRI 1945) telah sangat tepat ketika merumuskan tujuan didirikannya negara sebagaimana yang tercantum dalam Alinea Keempat yang berbunyi,

“Untuk membentuk suatu pemerintah negara Indonesia yang melindungi segenap bangsa Indonesia dan seluruh tumpah darah Indonesia dan untuk memajukan kesejahteraan umum, mencerdaskan kehidupan bangsa, dan ikut melaksanakan ketertiban dunia yang berdasarkan kemerdekaan, perdamaian abadi dan keadilan sosial, maka disusunlah kemerdekaan kebangsaan yang bebas itu dalam suatu Undang-Undang Dasar Negara Indonesia, yang terbentuk dalam suatu susunan negara Republik Indonesia yang berkedaulatan rakyat..."

Di antara pasal-pasal dalam UUDNRI 1945 yang relevan dengan penelitian ini adalah Pasal 27 ayat (2) UUDNRI 1945 yang berbunyi, "Tiap-tiap warga negara berhak atas pekerjaan dan penghidupan yang layak bagi kemanusiaan", dan Pasal 28D ayat (2) UUDNRI 1945 yang menyatakan, "Setiap orang berhak untuk bekerja serta mendapatkan imbalan dan perlakuan yang adil dan layak dalam hubungan kerja".

Berdasarkan ketentuan dalam kedua pasal tersebut, maka terdapat beberapa hak asasi manusia khususnya warga negara Indonesia, yaitu: (a) hak atas pekerjaan, (b) hak atas penghidupan yang layak, (c) hak untuk bekerja, (d) hak mendapatkan imbalan dari pekerjaannya, dan (e) hak mendapat perlakuan yang adil dan layak dalam hubungan kerja.Sebagai negara hukum, Indonesia harus mengimplementasikan norma-norma konstitusi tersebut dalam peraturan perundang-undangan sebagaimana diatur dalam Pasal 28I ayat (4) UUDNRI 1945 yang menyatakan, "Perlindungan, pemajuan, penegakan, dan pemenuhan hak asasi manusia adalah tanggung jawab negara, terutama pemerintah".

Guna mengimplementasikannya pemerintah telah membentuk peraturan perundang-undangan yang mengatur mengenai hukum perburuhan/ketenagakerjaan yang berisi hubungan antara buruh dengan majikannya. Hukum perburuhan tersebut berfungsi melindungi kepentingan buruh/pekerja terhadap kekuasaan yang tidak terbatas dari pihak majikannya. Masalah perburuhan/ketenagakerjaan diatur dalam Undang-Undang Nomor 13 Tahun 2003 tentang ketenagakerjaan. Selain itu berkenaan dengan perselisihan 
perburuhan diatur dalam Undang-Undang Nomor 22 Tahun 1957 tentang Penyelesaian Perselisihan Perburuhan, dan Undang-Undang Nomor 12 Tahun 1964 tentang Pemutusan Hubungan Kerja di Perusahaan Swasta. Kedua undangundang tersebut digantikan dengan Undang-Undang Nomor 2 Tahun 2004 tentang Penyelesaian Perburuhan.

Sebagai negara berkembang, Indonesia sedang giat-giatnya melaksanakan pembangunan di segala bidang. Pembangunan yang dilaksanakan mengalami perubahan paradigma, yakni dari orientasi agraris ke orientasi industri. Berbeda dengan negara-negara maju, Indonesia sebagai negara berkembang melaksanakan tahap-tahap pembangunan secara konkuren. ${ }^{1}$ Tahap industrialisasi yang menekankan pada akumulasi modal, dan tahap kesejahteraan masyarakat, berjalan bersamaan. Sementara itu, tahap unifikasi yang seharusnya menjadi prasyarat berhasilnya tahap industrialisasi, hingga saat ini masih belum sepenuhnya tuntas. Integrasi pasar barang dan jasa yang semakin meluas dan mendalam, memposisikan Indonesia pada situasi yang sulit dalam ekonomi pasar bebas.

Menurut Aloysius Uwiyono, hal ini karena ketiadaan atau kekurangan modal dari dalam negeri maupun rendahnya teknologi yang dikuasai Bangsa Indonesia. ${ }^{2}$ Ketiadaan dan rendahnya modal serta rendahnya teknologi tersebut menempatkan Indonesia sebagai salah satu negara yang tergantung pada modal luar negeri. Ketergantungan pertumbuhan ekonomi nasional pada modal asing masih sulit dihindari yang secara sadar maupun tidak sadar berada di bawah tekanan investor asing untuk menerapkan kebijakan upah murah dan pengaturan masalah perburuhan yang menguntungkan investor asing.

Hal-hal tersebut, sebenarnya menyulitkan posisi Indonesia karena di satu sisi harus memperhatikan kesejahteraan dan hak-hak buruh/tenaga kerja di sisi lain ketergantungan Indonesia pada modal asing yang berarti harus dengan upah rendah, sementara negara-negara maju menekan negara-negara

1 Erman Rajagukguk, Peranan Hukum Dalam Pembangunan Pada Era Globalisasi : Implikasi Bagi Pendidikan Hukum di Indonesia, (Jakarta: UI Press Cetakan Kedua, 1999), hlm. 6.

2 Aloysius Uwiyono, Problematika Hukum Perburuhan di Indonesia dan Solusinyam dalam Masalah-masalah Hukum Ekonomi Kontemporer (Fakultas Hukum Universitas Indonesia Lembaga Studi Hukum dan Ekonomi, 2006) hlm. 159. 
berkembang termasuk Indonesia untuk memperhatikan hak-hak buruh, melalui standar perburuhan dengan perdagangan internasional.

Masalah hubungan kerja antara buruh dan majikan atau perusahaan seringkali kurang mendapat perhatian. Di satu sisi, berbagai undang-undang telah memberikan jaminan hak-hak konstitusional buruh tetapi di sisi yang lain buruh masih merasa ada rekayasa norma yang merugikan hak-haknya.

\section{B. Permasalahan}

Permasalahan yang diangkat dalam penulisan artikel ini adalah sebagai berikut :

1. Bagaimanakah Pengaturan perlindungan hak konstitusional buruh dalam peraturan perundang-undangan?

2. Bagaimanakah konsep perlindungan Mahkamah Konstitusi terhadap hak konstitusional buruh?

\section{Metode}

Penulisan artikel ini menggunakan pendekatan normatif dalam menganalisis berbagaiperaturan perundang-undangandan putusan Mahkamah Konstitusi yang terkait dengan perlindungan hak-hak konstitusional buruh. Analisis dilakukan secara kualitatif.

\section{Pembahasan}

\section{Pengaturan Hak-hak Buruh dalam Peraturan Perundang-Undangan}

Sarjana Belanda bernama Molenar, sebagaimana dikutip oleh Iman Soepomo menyatakan bahwa hukum perburuhan (arbeidsrech) adalah bagian dari hukum yang berlaku dan pokoknya mengatur hubungan antara buruh dengan majikan, antara buruh dengan buruh, dan antara buruh dengan pengusaha. Istilah arbeidsrech dibatasi pada hukum yang bersangkutan dengan orang-orang yang berdasarkan perjanjian kerja, bekerja pada orang lain. Apabila buruh tersebut tidak lagi atau belum bekerja pada orang lain, tidak termasuk dalam pembahasan hukum perburuhan. ${ }^{3}$

\footnotetext{
${ }^{3}$ Iman Soepomo, Pengantar Hukum Perburuhan (Jakarta: Djambatan, 1995), hlm 1-2
} 
Hukum perburuhan sendiri adalah himpunan peraturan, baik tertulis maupun tidak tertulis dan berkenaan dengan kejadian tempat seseorang bekerja pada orang lain dengan menerima upah. ${ }^{4}$ Perlindungan hak buruh dalam peraturan perundang-undangan Indonesia diimplementasikan dalam berbagai peraturan perundang-undangan. Ada empat undang-undang yang mengatur mengenai perburuhan, yang di dalamnya adalah dalam rangka memberikan perlindungan hak buruh sekaligus juga tentunya memberikan perlindungan hak bagi pengusaha dan kepastian hukum dalam dunia usaha. Undang-undang yang berkaitan langsung dengan perburuhan/ketenagakerjaan adalah sebagai berikut:

\section{a. Undang-Undang Nomor 3 Tahun 1992 tentang Jaminan Sosial Tenaga Kerja}

Undang-Undang Nomor 3 Tahun 1992 tentang Jaminan Sosial Tenaga Kerja (selanjutnya disebut UU Jamsostek) diundangkan pada tanggal 17 Februari 1992 pada era Presiden Soeharto. UU Jamsostek tersebut dilatarbelakangi oleh kesadaran pembentuk undang-undang dalam rangka memberikan perlindungan bagi tenaga kerja karena semakin meningkatnya peranan tenaga kerja dalam perkembangan pembangunan dan semakin meningkatnya penggunaan teknologi di berbagai sektor kegiatan usaha yang dapat mengakibatkan semakin tinggi risiko yang mengancam keselamatan, kesehatan dan kesejahteraan tenaga kerja.

Di samping itu, perlindungan tenaga kerja yang melakukan pekerjaan baik dalam hubungan kerja maupun di luar hubungan kerja melalui program jaminan sosial tenaga kerja, selain memberikan ketenangan kerja juga mempunyai dampak positif terhadap usaha-usaha peningkatan disiplin dan produktivitas tenaga kerja. Oleh karena itu, Undang-Undang Nomor 2 Tahun 1951 tentang Pernyataan Berlakunya Undang-Undang Kecelakaan Tahun 1947 Nomor 33 dari Republik Indonesia untuk seluruh Indonesia (Lembaran Negara Tahun 1951 Nomor 3) dan Peraturan Pemerintah Nomor 33 Tahun 1977 tentang Asuransi Sosial Tenaga Kerja (Lembaran Negara Tahun 1977 Nomor 54, Tambahan

${ }^{4}$ Agusmidah, Dinamika \& Kajian Teori, Hukum Ketenagakerjaan Indonesia (Ghalia Indonesia: Bogor, 2010), hlm 4 
Lembaran Negara Nomor 3112) belum mengatur secara lengkap jaminan sosial tenaga kerja serta dipandang tidak sesuai lagi dengan kebutuhan hukum. ${ }^{5}$

Jaminan Sosial Tenaga Kerja oleh UU Jamsostek didefinisikan sebagai perlindungan bagi tenaga kerja dalam bentuk santunan berupa uang sebagai pengganti sebagian dari penghasilan yang hilang atau berkurang dan pelayanan sebagai akibat peristiwa atau keadaan yang dialami oleh tenaga kerja berupa kecelakaan kerja, sakit, hamil, bersalin, hari tua, dan meninggal dunia.

Penyelenggaraan jaminan sosial tenaga kerja dimaksudkan untuk memberikan perlindungan kepada tenaga kerja diselenggarakan program jaminan sosial tenaga kerja yang pengelolaannya dapat dilaksanakan dengan mekanisme asuransi sehingga setiap tenaga kerja berhak atas jaminan sosial tenaga kerja. Ruang lingkup program jaminan sosial tenaga kerja dalam Undang-Undang ini meliputi: 6
a. Jaminan Kecelakaan Kerja;
b. Jaminan Kematian;
c. Jaminan Hari Tua;
d. Jaminan Pemeliharaan Kesehatan.

Jaminan tersebut berlaku untuk tenaga kerja dan keluarga tenaga kerja. Pengusaha dan tenaga kerja wajib ikut serta dalam program jaminan sosial tenaga kerja. Oleh Karena itu, undang-undang mewajibkan pengusaha memiliki daftar tenaga kerja beserta keluarganya, daftar upah beserta perubahanperubahan, dan daftar kecelakaan kerja di perusahaan atau bagian perusahaan yang berdiri sendiri dan wajib menyampaikan data ketenagakerjaan dan data perusahaan yang berhubungan dengan penyelenggaraan program jaminan sosial tenaga kerja kepada Badan Penyelenggara.

Oleh karena pekerja yang memberikan tenaga dan pikirannya kepada pengusaha, maka UU Jamsostek menentukan bahwa iuran Jaminan Kecelakaan Kerja, iuran Jaminan Kematian, dan iuran Jaminan Pemeliharaan Kesehatan ditanggung oleh pengusaha, sedangkan iuran Jaminan Hari Tua ditanggung

\footnotetext{
${ }^{5}$ Konsiderans Menimbang UU Jamsostek.

${ }^{6}$ Pasal 6 ayat (1) UU Jamsostek.
} 
oleh pengusaha dan tenaga kerja. ${ }^{7}$ Penyelenggaraan program jaminan sosial tenaga kerja dilakukan oleh Badan Penyelenggara berupa Badan Usaha Milik Negara (BUMN) yang dibentuk dengan peraturan perundang-undangan yang berlaku, yang dalam melaksanakan fungsi dan tugasnya mengutamakan pelayanan kepada peserta dalam rangka peningkatan perlindungan dan kesejahteraan tenaga kerja beserta keluarganya. Badan Penyelenggara sebagaimana dimaksud dalam Pasal 25 ayat (2), wajib membayar jaminan sosial tenaga kerja dalam waktu tidak lebih dari 1 (satu) bulan.

Dalam UU Jamsostek diatur juga mengenai ketentuan pidana yakni pelanggaran terhadap ketentuan Pasal 4 ayat (1); Pasal 10 ayat (1), ayat (2), dan ayat (3); Pasal 18 ayat (1), ayat (2), ayat (3), ayat (4), dan ayat (5); Pasal 19 ayat (2); Pasal 22 ayat (1); dan Pasal 26, diancam dengan hukuman kurungan selamalamanya 6 (enam) bulan atau denda setinggi-tingginya Rp. 50.000.000,- (lima puluh juta rupiah). ${ }^{8}$ Berdasarkan norma-norma yang diatur dalam UU Jamsostek, dapat disimpulkan bahwa program Jamsostek memberikan perlindungan dasar untuk memenuhi kebutuhan minimal bagi tenaga kerja dan keluarganya.

\section{b. Undang-Undang Nomor 21 Tahun 2000 tentang Serikat Pekerja/Serikat Buruh}

Undang-Undang Nomor 21 Tahun 2000 tentang Serikat Pekerja/Serikat Buruh (selanjutnya disebut UU Serikat Pekerja) merupakan penjabaran dari hak konstitusional warga negara dalam hal berserikat dan berkumpul, mengeluarkan pendapat dengan lisan dan tulisan, serta merupakan implementasi dari hak konstitusional warga negara dalam mendapatkan pekerjaan yang layak bagi kemanusian. Hal ini tercermin dalam konsiderans menimbang undang-undang tersebut.

Oleh karena sedemikian vital hak-hak konstiusional tersebut, maka pembentuk undang-undang memandang perlu mewadahi dalam satu peraturan perundang-undangan, seperti yang dinyatakan dalam konsiderannya bahwa dalam rangka mewujudkan kemerdekaan berserikat, pekerja/buruh berhak membentuk dan mengembangkan serikat pekerja/serikat buruh yang bebas,

7 Pasal 20 ayat (1) UU Jamsostek.

8 Pasal 29 ayat (1) UU Jamsostek. 
terbuka; mandiri, demokratis, dan bertanggungjawab serta serikat pekerja/serikat buruh merupakan sarana untuk memperjuangkan, melindungi, dan membela kepentingan dan kesejahteraan pekerja/buruh beserta keluarganya, serta mewujudkan hubungan industrial yang harmonis, dinamis, dan berkeadilan.

Ketentuan tersebut dimaksudkan sebagai penjabaran dari Pasal 28 UUDNRI 1945. Dalam ketentuan-ketentuan tersebut, setiap pekerja/buruh diberikan kesempatan yang seluas-luasnya mendirikan dan menjadi anggota serikat pekerja/serikat buruh. Serikat pekerja/serikat buruh berfungsi sebagai sarana untuk memperjuangkan, melindungi, dan membela kepentingan dan meningkatkan kesejahteraan pekerja buruh dan keluarganya. Dalam menggunakan hak tersebut, pekerja/buruh dituntut bertanggung jawab untuk menjamin kepentingan yang lebih luas yaitu kepentingan bangsa dan negara.

Penggunaan hak tersebut dilaksanakan dalam kerangka hubungan industrial yang harmonis, dinamis, dan berkeadilan. Hak berserikat bagi pekerja/buruh, sebagaimana diatur dalam Konvensi International Labour Organization (ILO) Nomor 87 tentang Kebebasan Berserikat dan Perlindungan Hak Untuk Berorganisasi, dan Konvensi ILO Nomor 98 mengenai Berlakunya Dasar-dasar Daripada Hak Untuk Berorganisasi dan Untuk Berunding Bersama sudah diratifikasi oleh Indonesia menjadi bagian dari peraturan perundang-undangan nasional.

\section{c. Undang-Undang Nomor 13 Tahun 2003 tentang Ketenagakerjaan}

Undang-Undang Nomor 13 Tahun 2003 tentang Ketenagakerjaan (selanjutnya disebut UU Ketenagakerjaan) diundangkan pada tanggal 25 Maret 2003, sebagai pengganti dari beberapa ketentuan perundang-undangan yang berkaitan dengan perburuhan atau ketenagakerjaan yang sudah tidak sesuai lagi dengan perkembangan dan kesadaran hukum masyarakat. Undang-Undang tersebut dilatarbelakangi oleh kesadaran dari pembentuk undang-undang bahwa pembangunan nasional dilaksanakan dalam rangka pembangunan manusia Indonesia seutuhnya dan pembangunan masyarakat Indonesia seluruhnya untuk mewujudkan masyarakat yang sejahtera, adil, makmur, yang merata, baik materiil maupun spiritual berdasarkan Pancasila dan UUDNRI 1945. 
Di dalam pelaksanaan pembangunan nasional, tenaga kerja mempunyai peranan dan kedudukan yang sangat penting sebagai pelaku dan tujuan pembangunan. Sesuai dengan peranan dan kedudukan tenaga kerja, diperlukan pembangunan ketenagakerjaan untuk meningkatkan kualitas tenaga kerja dan peran sertanya dalam pembangunan serta peningkatan perlindungan tenaga kerja dan keluarganya sesuai dengan harkat dan martabat kemanusiaan. Perlindungan terhadap tenaga kerja dimaksudkan untuk menjamin hak-hak dasar pekerja/buruh dan menjamin kesamaan kesempatan serta perlakuan tanpa diskriminasi atas dasar apapun untuk mewujudkan kesejahteraan pekerja/buruh dan keluarganya dengan tetap memperhatikan perkembangan kemajuan dunia usaha. ${ }^{9}$

\section{d. Undang-Undang Nomor 2 Tahun 2004 tentang Penyelesaian Perselisihan} Hubungan Industrial.

Undang-Undang Nomor 2 Tahun 2004 tentang Penyelesaian Perselisihan Hubungan Industrial (selanjutnya disebut UU Perselisihan Hubungan Industrial), disahkan pada tanggal 14 Januari 2004 yang menggantikan UndangUndang Nomor 22 Tahun 1957 tentang Penyelesaian Perselisihan Perburuhan dan Undang-Undang Nomor 12 Tahun 1964 tentang Pemutusan Hubungan Kerja di Perusahaan Swasta.

UU Perselisihan Hubungan Industrial dilatarbelakangi oleh kesadaran dari pembentuk undang-undang bahwa hubungan industrial yang harmonis, dinamis, dan berkeadilan perlu diwujudkan secara optimal sesuai dengan nilainilai Pancasila. Dalam era industrialisasi, masalah perselisihan hubungan industrial menjadi semakin meningkat dan kompleks, sehingga diperlukan institusi dan mekanisme penyelesaian perselisihan hubungan industrial yang cepat, tepat, adil, dan murah. Oleh karena itu pembentuk undang-undang menilai Undang-Undang Nomor 22 Tahun 1957 tentang Penyelesaian Perselisihan Perburuhan dan Undang-Undang Nomor 12 Tahun 1964 tentang Pemutusan Hubungan Kerja di Perusahaan Swasta sudah tidak sesuai dengan kebutuhan masyarakat.

9 Lihat Konsiderans Menimbang huruf a sampai dengan huruf d UU Ketenagakerjaan. 
Beberapa ketentuan dalam UU Perselisihan Hubungan Industrial adalah:

(1) Tata cara penyelesaian perselisihan hubungan industrial;

(2) Pengadilan Hubungan Industrial;

(3) Penyelesaian perselisihan melalui pengadilan hubungan industrial;

(4) Sanksi administrasi dan ketentuan pidana.

Ketentuan-ketentuan dalam dalam undang-undang tersebut barulah ketentuan-ketentuan yang bersifat normatif, masih perlu ditinjau apakah undang-undang dimaksud cukup memberikan proteksi bagi buruh sebagai bagian dari warga negara yang harus mendapat perlindungan hak-hak konstitusionalnya.

Ketentuan-ketentuan normatif tersebut, dijabarkan dalam pasal-pasal dan peraturan perundang-undangan lain di bawah undang-undang, seperti peraturan pemerintah, peraturan presiden, peraturan menteri dan keputusan menteri tenaga kerja maupun peraturan daerah.

Penelaahan terhadap keempat undang-undang tersebut dimaksudkan untuk menemukan konsepsi perlindungan buruh yang secara garis besar dapat dirumuskan sebagai hak-hak normatif buruh. Hak normarif buruh merupakan hak dasar buruh dalam hubungan kerja yang dilindungi dan dijamin dalam peraturan perundang-undangan yang berlaku. Pengusaha mempunyai kewajiban untuk memenuhi dan mematuhi hak normatif buruh dalam setiap pemberian kerja. Hak-hak normatif buruh Penulis diklasifikasikan menjadi tiga hak, yakni: (1) Hak yang bersifat ekonomis. Misalnya upah, tunjangan hari raya (THR), tunjangan hari tua, fasilitas perumahan, dan lainnya, (2) Hak yang bersifat politis. Misalnya hak membentuk serikat buruh, hak menjadi atau tidak menjadi anggota serikat buruh, hak mogok, hak tidak diskrimintaif, dan lainnya, (3) Hak yang bersifat sosial. Misalnya hak cuti, kawin, libur resmi, pembatasan pekerjaan anak dan perempuan pada malam hari, dan lainnya. (4) Hak yang bersifat medis berupa hak-hak atas keselamatan dan kesehatan kerja, hak melahirkan, hak istirahat, hak menyusui anak, hak atas jaminan pemeliharaan kerja, larangan mempekerjakan anak, dan lainnya. 


\section{Konsep Perlindungan Mahkamah Konstitusi terhadap hak konstitusional buruh}

Berdasarkan wewenang yang dimiliki, Mahkamah Konstitusi merupakan pengawal konstitusi (the guardian of the constitution) terkait dengan empat wewenangnya dan satu kewajiban yang dimilikinya. Hal itu juga membawa konsekuensi Mahkamah Konstitusi berfungsi sebagai penafsir konstitusi (the sole interpreter of the constitution). Kewenangan tersebut diberikan dengan tujuan agar Mahkamah Konstitusi mengawal ketentuan-ketentuan dalam konstitusi tidak sekedar menjadi kumpulan huruf dan kalimat mati, melainkan terjelma dan dipraktikan dalam kehidupan bernegara. Kewenangan demikian diberikan juga dalam rangka memperkuat mekanisme kontrol (checks and balances) yang mutlak diperlukan guna membangun struktur dan sistem ketatanegaraan yang lebih demokratis.

Konstitusi sebagai hukum tertinggi mengatur penyelenggaraan negara berdasarkan prinsip demokrasi dan salah satu fungsi konstitusi adalah melindungi hak asasi manusia yang dijamin dalam konstitusi sehingga menjadi hak konstitusional warga negara. Oleh karena itu Mahkamah Konstitusi juga berfungsi sebagai pengawal demokrasi (the guardian of the democracy), pelindung hak konstitusional warga negara (the protector of the citizen's constitutional rights) serta pelindung hak asasi manusia (the protector of human rights).

Dalam Putusan mahkamah Konstitusi pada Perkara Nomor 012/PUUI/2003, adalah merupakan penafsiran hukum Mahkamah Konstitusi terhadap UUDNRI 1945 terkait dengan pengujian Undang-UndangKetenagakerjaan.Tafsir konstitusional tersebut diwujudkan dalam pendapat Mahkamah Konstitusi terhadap pasal-pasal yang dimohonkan pengujian. Dari analisa yang Penulis lakukan, terdapat beberapa pandangan hukum Mahkamah Konstitusi yang merupakan konsepsi perlindungan hukum terhadap buruh, yakni:Pasal yang mengatur mengenai kewenangan pengusaha melakukan PHK terhadap buruh dengan alasan buruh/pekerja telah melakukan kesalahan berat tanpa due process of law melalui putusan pengadilan yang independen dan imparsial, melainkan cukup hanya dengan keputusan pengusaha yang didukung oleh bukti-bukti yang tidak perlu diuji keabsahannya menurut hukum acara yang berlaku. 
Sementara, di lain pihak, Pasal 160 menentukan secara berbeda bahwaburuh/pekerja yang ditahan oleh pihak yang berwajib karena diduga melakukan tindak pidana tetapi bukan atas pengaduan pengusaha, diperlakukan sesuai dengan asas praduga tidak bersalah (presumption of innocence) yang sampai bulan keenam masih memperoleh sebagian dari hak-haknya sebagai buruh, dan apabila pengadilan menyatakan buruh/pekerja yang bersangkutan tidak bersalah, pengusaha wajib mempekerjakan kembali buruh/pekerja tersebut dengan bentuk perlakuan diskriminasi atau berbeda di dalam hukum.

Pasal 159 yang menentukan, apabila buruh/pekerja yang telah di-PHK karena melakukan kesalahan berat menurut Pasal 158, tidak menerimapemutusan hubungan kerja, pekerja/buruh yang bersangkutandapat mengajukan gugatan ke lembaga penyelesaian perselisihan industrial,oleh Mahkamah Konstitusi dipandang melahirkan beban pembuktian yang tidak adil dan berat bagi buruh/pekerja untuk membuktikan ketidaksalahannya, sebagai pihak yang secara ekonomis lebih lemah yang seharusnya memperoleh perlindungan hukum yang lebih dibanding pengusaha, Pasal 159 juga menimbulkan kerancuan berpikirdengan mencampuradukkan proses perkara pidana dengan proses perkara perdata secara tidak pada tempatnya.

Sanksi mogok kerja sebagaimana diatur dalam Pasal 186 UU Ketenagakerjaantidakproporsional karena mereduksi hak mogok yang merupakan hak dasar buruh yang dijamin oleh UUDNRI 1945 dalam rangka kebebasan menyatakan sikap [Pasal 28E ayat (2) dan ayat (3)] dan hak untuk mendapat imbalan yang adil dan layak dalam hubungan kerja [Pasal 28D ayat (2)].

Terkait dengan konsep perlindungan buruh yang diatur dalam UU ketenagakerjaan menurut Mahkamah Konstitusi tidak tegas karena kurang memperhitungkan keseimbangan berbagai kepentingan, khususnya kepentingan buruh dan kepentingan pengusaha dalam mekanisme ekonomi pasar. Kepentingan pengusaha harus juga diakomodasi karena ketiadaan investasi justru akan menyebabkan berkurangnya lapangan kerja dan bertambahnya pengangguran yang pada gilirannya justru akan merugikan pihak buruh sendiri sehingga Pasal 33 UUDNRI 1945 tidak dapat dipahami sepenuhnya sebagai penolakan terhadap sistem ekonomi pasar, yang berarti mengharuskan negara 
melakukan campur tangan tatkala mekanisme ekonomi pasar mengalami distorsi.

Terkait dengan penyediaan tenaga kerja atau yang lebih dikenal outsourcing sebagaimana diatur dalam Pasal 64 sampai dengan Pasal 66 UU Ketenagakerjaan dipandang oleh Mahkamah Konstitusi telah menjelaskan keberadaan dan batasan dari outsourcing tersebut sebagai bagian dari pekerjaan yang terpisah dari kegiatan utama yang merupakan kegiatan penunjang perusahaan secara keseluruhan yang tidak menghambat proses produksi secara langsung. Pelaksanaan pekerjaan tersebut diserahkan oleh suatu perusahaan kepada perusahaan lainnya dengan perjanjian pemborongan pekerjaan atau penyediaan jasa pekerja/buruh yang dibuat secara tertulis. Buruh/pekerja dimaksud tidak boleh digunakan oleh pemberi kerja untuk melaksanakan kegiatan pokok atau kegiatan yang berhubungan langsung dengan proses produksi, sehingga hubungan kerja antara buruh/pekerja outsourcing adalah dengan perusahaan penyedia jasa pekerja/buruh.

Dalam pendapatnya Mahkamah Konstitusi menilai bahwa perlindungan yang diberikan terhadap buruh outsourcing tampak dalam Pasal 66 ayat (1), (2) a, c dan ayat (4) UU Ketenagakerjaan. Akan tetapi, dalam hal buruh dimaksud ternyata dipekerjakan untuk melaksanakan kegiatan pokok, tidak ada hubungan kerja dengan perusahaan penyedia jasa pekerja/buruh, dan jika perusahaan penyedia jasa pekerja/buruh bukan merupakan bentuk usaha yang berbadan hukum, menurut Mahkamah Konstitusi status hubungan kerja antara pekerja/buruh dan perusahaan penyedia jasa pekerja/buruh demi hukum beralih menjadi hubungan kerja antara pekerja/buruh dengan perusahaan pemberi pekerjaan.

Hubungan kerja antara buruh dengan perusahaan penyedia jasa yang melaksanakan pelaksanaan pekerjaan pada perusahaan lain, mendapat perlindungan kerja dan syarat-syarat yang sama dengan perlindungan kerja dan syarat-syarat kerja pada perusahaan pemberi pekerjaan atau sesuai dengan peraturan perundang-undangan yang berlaku. Oleh karenanya, terlepas dari jangka waktu tertentu yang mungkin menjadi syarat perjanjian kerja demikian dalam kesempatan yang tersedia, maka perlindungan hak-hak buruh sesuai dengan aturan hukum dalam UU Ketenegakerjaan, tidak terbukti bahwa hal itu 
menyebabkan sistem outsourcing merupakan modern slavery dalam proses produksi.

Adanya ketentuan dalam UU Ketenagakerjaan yang pada intinya mengatur hanya ada satu PKB dalam satu perusahaan, dinilai Mahkamah Konstiusi sebagai sesuatu yang wajar karena aturan yang mensyaratkan satu serikat buruh/pekerja di perusahaan memperoleh hak untuk mewakili pekerja/buruh dalam perundingan pembuatan Perjanjian Kerja Bersama apabila memiliki jumlah anggota lebih dari 50\% dari jumlah seluruh pekerja/buruh di perusahaan yang bersangkutan, dan jikalau jumlah 50\% tidak tercapai, untuk dapat berunding serikat buruh/pekerja yang bersangkutan memerlukan dukungan lebih dari 50\% dari seluruh jumlah buruh/pekerja, yang akan dicapai oleh serikat buruh/pekerja melalui musyawarah dan mufakat di antara sesama buruh/pekerja, sedang jika serikat buruh/pekerja lebih dari satu dan tidak mencapai jumlah lebih dari 50\%, dapat dilakukan koalisi di antara serikat buruh/pekerja di perusahaan tersebut untuk mewakili buruh dalam perundingan dengan pengusaha, dan jika hal inipun tidak dicapai tim perunding ditentukan secara proporsional berdasarkan jumlah anggota masing-masing serikat buruh/pekerja. Begitu pula terkait dengan kartu anggota oleh Mahkamah Konstitusi tidak dipandang bertentangan dengan UUDNRI 1945 karena persyaratan kartu anggota sebagai alat bukti bagi tanda keanggotaan seseorang dalam satu serikat pekerja/buruh, adalah merupakan hal yang wajar dalam organisasi untuk dapat secara sah menyatakan klaim mewakili anggota.

Adanya Lembaga Kerja Sama Bipartit dalam perusahaan yang mempekerjakan 50 orang buruh atau lebih, yang berfungsi sebagai forum komunikasi dan konsultasi mengenai hal ketenagakerjaan di perusahaan yang bersangkutan, Menurut Mahkamah Konstiusi tidak dapat ditafsirkan meniadakan hak organisasi buruh/pekerja untuk memperjuangkan hak dan kepentingan buruh/pekerja, karena penunjukan unsur buruh/pekerja yang akan duduk dalam forum tersebut dilakukan secara demokratis, yang dapat ditarik setiap saat jika ternyata bukan kepentingan buruh yang dipertahankan dalam forum konsultasi dimaksud.

Pasal dalam UU Ketenagakerjaan yang oleh Mahkamah Konstisui dipandang bertentangan dengan UUDNRI 1945 adalah pasal yang mengatur 
mengenai kewenangan pengusaha melakukan PHK terhadap buruh dengan alasan buruh/pekerja telah melakukan kesalahan berat tanpa due process of law melalui putusan pengadilan yang independen dan imparsial, melainkan cukup hanya dengan keputusan pengusaha yang didukung oleh bukti-bukti yang tidak perlu diuji keabsahannya menurut hukum acara yang berlaku.

Sementara, di lain pihak, Pasal 160 menentukan secara berbeda bahwa buruh/pekerja yang ditahan oleh pihak yang berwajib karena diduga melakukan tindak pidana tetapi bukan atas pengaduan pengusaha, diperlakukan sesuai dengan asas praduga tidak bersalah (presumption of innocence) yang sampai bulan keenam masih memperoleh sebagian dari hak-haknya sebagai buruh, dan apabila pengadilan menyatakan buruh/pekerja yang bersangkutan tidak bersalah, pengusaha wajib mempekerjakan kembali buruh/pekerja tersebut. Hal inilah yang dipandang sebagai bentuk perlakuan diskriminasi atau berbeda di dalam hukum sehingga dinilai bertentangan dengan UUDNRI 1945.

Bentuk pelanggaran terhadap hak konstitusional buruh sebagai warga negara juga ditemukan Mahkamah Konstitusi pada UU Ketenagakerjaan, yakni dalam Pasal 159 yang menentukan, apabila buruh/pekerja yang telah di-PHK karena melakukan kesalahan berat menurut Pasal 158, tidak menerima pemutusan hubungan kerja, pekerja/buruh yang bersangkutan dapat mengajukan gugatan ke lembaga penyelesaian perselisihan industrial, oleh Mahkamah Konstitusi dipandang melahirkan beban pembuktian yang tidak adil dan berat bagi buruh/pekerja untuk membuktikan ketidaksalahannya, sebagai pihak yang secara ekonomis lebih lemah yang seharusnya memperoleh perlindungan hukum yang lebih dibanding pengusaha, Pasal 159 juga menimbulkan kerancuan berpikir dengan mencampuradukkan proses perkara pidana dengan proses perkara perdata secara tidak pada tempatnya.

Sanksi mogok kerja sebagaimana diatur dalam Pasal 186 UU Ketenagakerjaan dipandang Mahkamah Konstitusi sebagai tidak proporsional karena mereduksi hak mogok yang merupakan hak dasar buruh yang dijamin oleh UUDNRI 1945 dalam rangka kebebasan menyatakan sikap [Pasal 28E ayat (2) dan ayat (3)] dan hak untuk mendapat imbalan yang adil dan layak dalam hubungan kerja [Pasal 28D ayat (2)]. 
Dari analisis terhadap Putusan Mahkamah Konstitusi dapat disimpulkan bahwa terdapat beberapa ketentuan dalam UU Ketenagakerjaan yang bertentangan dengan UUDNRI 1945, yakni: (1) Pasal 158, (2) Pasal 159, (3) Pasal 160 ayat (1) sepanjang mengenai anak kalimat “... bukan atas pengaduan pengusaha ...", (4) Pasal 170 sepanjang mengenai anak kalimat “... kecuali Pasal 158 ayat (1), ..." (5) Pasal 171 sepanjang menyangkut anak kalimat “... Pasal 158 ayat (1)...", dan (6)Pasal 186 sepanjang mengenai anak kalimat "... Pasal 137 dan Pasal 138 ayat (1)..."

Namun demikian, dalam putusan Mahkamah Konstitusi tersebut terdapat pendapat yang berbeda yang pada intinya menyatakan bahwa “outsourcing" yang tercantum dalam Pasal 64, Pasal 65 dan Pasal 66 UU Ketenagakerjaan dinilai mengganggu ketenangan kerja bagi buruh/pekerja yang sewaktu-waktu dapat terancam pemutusan hubungan kerja (PHK) dan mendowngrading-kan buruh sekedar sebagai sebuah komoditas, sehingga berwatak kurang protektif terhadap buruh/pekerja dan karenanya tidak sesuai dengan paradigma proteksi kemanusiaan yang tercantum dalam Pembukaan UUDNRI 1945 dan bertentangan dengan Pasal 27 ayat (2) UUDNRI 1945.

Pemberatan persyaratan untuk merundingkan Perjanjian Kerja Bersama (PKB) bagi serikat buruh/serikat pekerja, merupakan kebijakan terselubung guna mengurangi hak buruh/pekerja untuk memperjuangkan hak-haknya dan mereduksi hakikat kebebasan berserikat/berorganisasi bagi buruh/pekerja seperti yang dijamin oleh Pasal 28 UUDNRI 1945.

\section{E. Simpulan}

Konsep perlindungan hak buruh dalam konstitusi secara normatif telah tercermin dalam berbagai peraturan perundang-undangan yang menjamin hakhak konstitusional buruh atau hak-hak normatif buruh. Pengaturan tersebut secara garis besar dapat dikelompokkan menjadi empat, yakni hak yang bersifat ekonomis, hak yang bersifat politis, hak yang bersifat medis, dan hak yang bersifat sosial. Konsepsi Perlindungan Hak Buruh Menurut Mahkamah Konstitusi sebagaimana tercermin dalam Putusan Perkara Nomor 012/PUUI/2003 adalah merupakan penafsiran hukum Mahkamah Konstitusi terhadap UUDNRI 1945 terkait dengan pengujian Undang-Undang Ketenagakerjaan. 


\section{Daftar Pustaka}

\section{Buku :}

Agusmidah, 2010, Dinamika \& Kajian Teori, Hukum Ketenagakerjaan Indonesia, Ghalia Indonesia, Bogor.

Erman, Rajagukguk, 1997, Peranan Hukum Dalam Pembangunan Pada Era Globalisasi: Implikasi Bagi Pendidikan Hukum di Indonesia, Pidato Pengukungan diucapkan pada Upacara Penerimaan Jabatan Guru Besar dalam Bidang Hukum pada Fakultas Hukum Universitas Indonesia, Jakarta.

Imam, Soepomo, 1985, Pengantar Hukum Perburuhan, Djembatan, Jakarta.

Aloysius, Uwiyono, 2006, Problematika Hukum Perburuhan di Indonesia dan Solusinya,dalam Masalah-masalah Hukum Ekonomi Kontemporer,Ed. Ridwan Khairandy, Fakultas Hukum Universitas Indonesia Lembaga Studi Hukum dan Ekonomi, Jakarta.

\section{Peraturan Perundang-undangan}

Indonesia, Undang-Undang Dasar Negara Republik Indonesia Tahun 1945.

Undang-Undang tentang Jaminan Sosial Tenaga Kerja, Nomor 3 Tahun 1992 Lembaran Negara RI Tahun 1992 Nomor 14, Tambahan Lembaran Negara RI Nomor 3468.

Undang-Undang tentang Serikat Pekerja/Serikat Buruh, Nomor 21 Tahun 2000 Lembaran Negara RI Tahun 2000 Nomor 131, Tambahan Lembaran Negara RI Nomor 3989.

Undang-Undang tentang Ketenagakerjaan, Nomor 13 Tahun 2003 Lembaran Negara RI Tahun 2003 Nomor 39, Tambahan Lembaran Negara RI Nomor 4279 .

Undang-Undang tentang Penyelesaian Perselisihan Hubungan Industrial, Nomor 2 Tahun 2004 Lembaran Negara RI Tahun 2004 Nomor 6, Tambahan Lembaran Negara RI Nomor 4356. 